\title{
Using Drugs to Keep Learning Active During a Pandemic
}

\author{
Michael W. Lee $e^{1,2,3}$ (1)
}

Published online: 10 July 2020

(C) International Association of Medical Science Educators 2020

\section{Teaching Pharmacology Remotely Using a Flipped-Classroom Approach}

The rapid switch to delivering material via web-conferencing modalities such as Zoom@ $\odot$ has been an adjustment for both students and faculty, particularly for schools with a heavy active-learning-based curriculum. At the Dell Medical School (DMS), we employ a flipped-classroom approach to deliver the first-year basic sciences $[1,2]$. In our flippedclassroom sessions at DMS, students view videos, listen to podcasts, or engage with tailored pre-reading prior to coming to the class where they work in small group activities (approximately 5 students per group). Maintaining small group active learning during the COVID-19 pandemic using distance learning is a challenge fraught with barriers [3].

One promising strategy that I used to deliver active, flipped-classroom pharmacology sessions entails using the breakout room feature of Zoom@ $\odot$. This simple act of splitting students up into smaller groups appears to come close to approximating small group interaction typically leveraged in the classroom. For example, Zoom@ $\odot$ breakout rooms were used in tandem with a flipped-classroom activity to cover the clinical pharmacology of drugs for diabetes, including clinically relevant adverse effects and pharmacokinetics.

In this session, students were provided a blank table with missing variables and information on the common and serious adverse effects, lipid changes, ability to cause weight gain or weight loss, and route of administration for representative

Michael W. Lee

Lee_Michael@austin.utexas.edu

1 Department of Medical Education, Dell Medical School, University of Texas at Austin, Austin, TX, USA

2 Department of Oncology, Dell Medical School, University of Texas at Austin, Austin, TX, USA

3 Live Strong Cancer Institutes, Dell Medical School, University of Texas at Austin, Health Learning Building, 1501 Red River Street, MC: Z0100, Austin, TX 78712, USA agents from each of the major classes of drugs used to treat diabetes (Fig. 1).

Prior to the session, students were asked to watch a brief video on the pharmacology of the drugs for diabetes with a focus on the adverse effects and pharmacokinetics (mechanism of action, while revisited in the video, was covered in the first half of the year). The following day, a set of instructions and the table were provided "just-in-time" at the start of the 30-min-long session.

Briefly, students were randomly assigned to one of eight groups (corresponding to a single diabetes drug row on the table in Fig. 1). The students were instructed to work together for $15 \mathrm{~min}$ to assemble the information to populate the table for their groups' drug and select a "spokesperson" who would present their findings to the overall class upon reconvening. Students were encouraged to "recall" the information they learned from the pre-class video. Thus, there are loose, but deliberately incorporated, elements of both peer-instruction and retrieval practice built into the exercise [4]. As the students worked in their groups, I moved back and forth among the groups as an observer. Following small group discussions in the breakout rooms, students were brought back to the main room where their spokesperson reported out their findings. The correct answers were then sequentially revealed to the class following each groups' online presentation. A total of 40 students (out of 50 students) in our M1 class of 2023 were in attendance for this session. Therefore, despite organizing and deploying this emergency remote teaching session at a moment's notice at the beginning of the pandemic lockdown, it came close to replicating the flipped-classroom environment we typically use in-person with similar numbers of students and levels of engagement.

Pedagogically, one of the goals of this session is for students to "retrieve" information they learned the night before from the video for discussion with their group, thereby strengthening their memory retention of the information. Additionally, inclusion of a column on "lipid changes" induced by the different agents, which can vary depending on the source or reference you consult, proved to be a key 


\begin{tabular}{|c|c|c|c|c|c|c|c|}
\hline Class & Prototype & $\begin{array}{l}\text { Common } \\
\text { ADR }\end{array}$ & $\begin{array}{c}\text { Weight } \\
\text { Gain } \\
(\mathrm{Y} / \mathrm{N})\end{array}$ & $\begin{array}{l}\text { Serious } \\
\text { ADR }\end{array}$ & $\begin{array}{l}\text { Hypoglycemia } \\
\text { (low-high) }\end{array}$ & $\begin{array}{l}\text { Lipid } \\
\text { Effects }\end{array}$ & $\begin{array}{c}\text { Route of } \\
\text { Administration }\end{array}$ \\
\hline Biguanides & Metformin & $\begin{array}{l}\text { Gl fx } \\
\text { (diarrhea, } \\
\text { N/V) }\end{array}$ & $\begin{array}{l}\text { No } \\
\text { (weight } \\
\text { loss) }\end{array}$ & $\begin{array}{l}\text { lactic acidosis, B12 } \\
\text { deficiency }\end{array}$ & Low-none & $\begin{array}{l}\text { LDL: } \downarrow \\
\text { TG: } \downarrow \\
\text { HDL: } \uparrow\end{array}$ & Oral \\
\hline Sulfonylureas & Glyburide & & & & & $\begin{array}{l}\text { LDL: } \\
\text { TG: } \\
\text { HDL: }\end{array}$ & \\
\hline Meglitinides & Repaglinide & & & & & $\begin{array}{l}\text { LDL: } \\
\text { TG: } \\
\text { HDL: }\end{array}$ & \\
\hline Thiazolidinediones & Pioglitazone & & & & & $\begin{array}{l}\text { LDL: } \\
\text { TG: } \\
\text { HDL: }\end{array}$ & \\
\hline $\begin{array}{l}\alpha \text {-glucosidase } \\
\text { Inhibitors }\end{array}$ & Miglitol & & & & & $\begin{array}{l}\text { LDL: } \\
\text { TG: } \\
\text { HDL: }\end{array}$ & \\
\hline GLP-1 agonists & Exenatide & & & & & $\begin{array}{l}\text { LDL: } \\
\text { TG: } \\
\text { HDL: }\end{array}$ & \\
\hline DPP-4 Inhibitors & Sitagliptin & & & & & $\begin{array}{l}\text { LDL: } \\
\text { TG: } \\
\text { HDL: }\end{array}$ & \\
\hline SGL-2 Inhibitors & Empagliflozin & & & & & $\begin{array}{l}\text { LDL: } \\
\text { TG: } \\
\text { HDL: }\end{array}$ & \\
\hline $\begin{array}{l}\text { Amylin peptide } \\
\text { analogs }\end{array}$ & Pramlintide & & & & & $\begin{array}{l}\text { LDL: } \\
\text { TG: } \\
\text { HDL: }\end{array}$ & \\
\hline
\end{tabular}

Fig. 1 Remote Online flipped-classroom exercise on diabetes clinical pharmacology. An Example a of flipped-classroom activity that was used to foster group learning via distance learning platforms such as Zoom(C)

learning point about ambiguity. Indeed, many of the groups came up with different "lipid changes" and this furnished the opportunity for a teachable moment: that when they encounter diabetes drugs, they may not remember the specific lipid level changes, but they should remember that these drugs can alter serum lipids.

Interestingly, based on observations from the session, it appeared that students were less apprehensive about presenting in this "socially removed" web-conferencing platform as opposed to standing up in front of a classroom full of people. Indeed, there is evidence that supports the notion that incorporation of online learning as part of a "blended learning approach" may reduce student anxiety, but clearly more study is needed [5].

It remains to be determined how presenting this material in an online format will affect student performance on formative and summative assessments, but a recent meta-analysis suggests that those differences may be minor, but slightly favor online learning [6]. However, given the role that faculty and students play in modeling professionalism, curiosity, and social norms, I believe that both faculty and students would stand to lose were we to replace in-person sessions in favor of online learning.

\section{Compliance with Ethical Standards}

Conflict of Interest The author wishes to declare he is the owner and creator of Pharmacology World LLC.

\section{References}

1. Lee MW, Steinel N. Flipped Classroom: does classroom attendance and participation matter for mastery? FASEB J. 2019, 33(1_supplement):598.9-.9. https://doi.org/10.1096/fasebj.2019.33.1_ supplement.598.9.

2. Steinel N, Palmer GC, Nowicki E, Lee E, Nelson E, Whiteley M, et al. Integration of microbiology, pharmacology, immunology, and infectious disease using active teaching and self-directed learning. Med Sci Educ. 2019;29(1):315-24. https://doi.org/10.1007/s40670018-00689-8.

3. O'Doherty D, Dromey M, Lougheed J, Hannigan A, Last J, McGrath D. Barriers and solutions to online learning in medical education - an integrative review. BMC Med Educ. 2018;18(1):130. https://doi.org/ 10.1186/s12909-018-1240-0.

4. Roediger HL 3rd, Butler AC. The critical role of retrieval practice in long-term retention. Trends Cogn Sci. 2011;15(1):20-7. https://doi. org/10.1016/j.tics.2010.09.003.

5. Rogers J, Smith AM, Ham Y, Russell J-eM. Course delivery format and exam performance stratified by question difficulty. The FASEB Journal. 2019;33(1 supplement):598.2-.2. https://doi.org/10.1096/ fasebj.2019.33.1_supplement.598.2.

6. Pei L, Wu H. Does online learning work better than offline learning in undergraduate medical education? A systematic review and metaanalysis. Med Educ Online. 2019;24(1):1666538. https://doi.org/10. 1080/10872981.2019.1666538.

Publisher's Note Springer Nature remains neutral with regard to jurisdictional claims in published maps and institutional affiliations. 